\title{
The mood of the nation in 2020: \\ The Stuff/Massey pre-election online survey
}

\author{
Grant Duncan, James H. Liu and Sarah Y. Choi \\ Massey University, Auckland, New Zealand
}

\begin{abstract}
Leading up to the 2017 New Zealand general election, Stuff.co.nz and Massey University collaborated in two online surveys of public opinion to test the mood of the nation and seek opinions about a range of relevant political and social issues. Given their success, two more surveys were conducted in 2020. This article summarises results from the 2020 data, and reflects on the methodological advantages, disadvantages and challenges of conducting people-driven online surveys that need to meet the differing needs of academic researchers, journalists and the public. While the surveys produced very large samples, they were not representative. Moreover, the choices of items were influenced by what happened to be newsworthy at the time. Naturally, Covid-19 was a significant theme during the 2020 surveys. The results reveal predictable left-right polarization of opinions, a minority support for conspiracy theories, some areas of wide agreement across the political spectrum, and some unexpected nuances of opinions within and across ethnic groups.
\end{abstract}

Key words: New Zealand; opinion polls; political opinions; online survey

Cite as: Duncan, G., Liu, J.H., and Choi, S.Y. (2021). The mood of the nation in 2020: The Stuff/Massey pre-election online survey. Aotearoa New Zealand Journal of Social Issues, vol 1. URL: https://ojs.aut.ac.nz/anzjsi/article/view/6 


\section{Introduction}

In 2017 two online pre-election surveys were conducted in a collaboration between Massey University and Stuff.co.nz. The first was in May during the week of the government's Budget; the second in August during the week in which Jacinda Ardern became leader of the Labour Party (Duncan, 2018). These opinion surveys aimed to provide quick feedback to readers preceding the election, and hence to stimulate political debate and reflection. They were not designed to help voters 'discover which party's policies are closest to their preferences' - aims which had been met by Vote Compass (Lees-Marshment et al., 2015, p. 96). But the Vote Compass and the Stuff/Massey surveys both illustrate the increasing utility of online surveys, allowing for methodological limitations (see below).

In the period 2016-18, political scientists internationally had been largely preoccupied with the rise of populism, especially the unexpected victory of President Donald Trump and Britain's referendum result in favour of leaving the European Union in 2016. There were concerns about a decline in popular trust in politicians and in government per se, reflected in declining voter turnouts (Pew Research Center, 2015; Runciman, 2017; Solijonov, 2016; Twenge, Campbell, \& Carter, 2014), plus the decline of social democracy, the rise of far-right populist parties and the disruptive impact of the Trump presidency (Cuperus, 2018; Friedman, 2016; Ries, 2017; Wedel, 2016). Political polarization in the United States was leading to conflict and stalling progress in policymaking (Hetherington \& Rudolph, 2015; Mason, 2018). In western Europe, the combination of right-wing anti-immigrant pariah parties and fragmentation in the centre and left of the political spectrum meant that government-formation was difficult and the outcomes were often ideologically incompatible and unstable coalitions (Grzymala-Busse, 2019; Mudde, 2019). Expectations that representative democratic political systems would spread and consolidate around the world were being challenged as setbacks, for example in Hungary, Poland and Turkey, outnumbered instances of progress (Abramowitz, 2018), and political scientists speculated about the demise of democracy itself (Foa \& Mounk, 2017; Levitsky \& Ziblatt, 2018; Mounk, 2018; Runciman, 2018; van der Meer \& Zmerli, 2017). In New Zealand, the trends in political distrust were not as negative as elsewhere; indeed, like some other small countries, and unlike the US, UK and Australia, dissatisfaction with democracy had declined there since the change to proportional representation in 1996 (Foa, Klassen, Slade, Rand, \& Williams, 2020). Moreover, the centre-right National Party was enjoying its third straight term in office while the Labour Party languished in opposition, suffering a fate comparable to social-democratic parties internationally (Duncan, 2018a).

Hence the 2017 Stuff/Massey survey focussed on themes of political distrust and immigration, among other concerns. It identified a considerable level of distrust in the political system, a desire for change and a strong current of opinion that could have fed a right-wing populist movement (Duncan, 2018b). There was a concern that this could be exploited for electoral purposes by the centrist-populist political party New Zealand First during the election campaign. 


\section{The 2017 election}

During May 2017, the governing National Party was polling between 43 and 49\%, and so it looked like the election could result in a National-New Zealand First coalition government. The outcome was quite different, however. With Labour's polling heading below $25 \%$, on 1 August leader Andrew Little stood down in favour of Jacinda Ardern. Coincidentally, the second round of the Stuff/Massey survey was running at that time. An influx of Labour supporters was noticed as data were being gathered. In both of the surveys that year Labour supporters were significantly under-represented, however. In round one, they were only $18.2 \%$, and in round two, $27.6 \%$. Many respondents in round two wrote free-text comments that they would now vote for Labour due to Ardern's rise to party leader. Publicly reported opinion polls also registered a significant boost for the Labour Party, going over $40 \%$ in the following month.

The election campaign in the mainstream media was dominated by debates between party leaders Bill English for National and Jacinda Ardern for Labour. English was the seasoned conservative politician who had served as deputy prime minister and finance minister under John Key, and as prime minister since December 2016; Ardern was the young rising star and her candidacy attracted considerable international media attention. Significant policy issues were child poverty, housing affordability, climate change and the environment. Immigration turned out not to be a leading election issue: NZ First didn't use it as a prominent campaign theme, as they were positioning themselves to be a coalition party in government and didn't want to become a pariah (with whom no major party could form a government) like some of the far-right parties in Europe.

The New Zealand general election on 23 September 2017 resulted in a hung parliament with NZ First holding the balance of power. The National Party won the highest number of party votes (44.4\%) ahead of Labour (36.9\%). Neither major party was able to form a government without the support of NZ First (and, in Labour's case, also requiring the Green Party) and so negotiations began. The outcome was a Labour-NZ First coalition government supported on confidence and supply by the Green Party. The latter gained ministerial portfolios outside cabinet. This was the first time in New Zealand that an MMP (mixed-member proportional) election had resulted in the party with the most party votes failing to form and lead the subsequent government.

The Stuff/Massey round two pre-election survey had fortuitously asked, 'What is your view on a possible Labour-NZ First-Green coalition government?' And 54.4\% had ticked the option that read 'a political shambles that won't last long', an opinion almost universally shared by National supporters (92.9\%). When asked whether they would prefer to see NZ First working with National or with Labour in government, or 'staying in opposition', NZ First supporters were evenly split: $46.3 \%$ preferred to go with National, $41.0 \%$ with Labour, and $12.7 \%$ to remain in opposition. Whichever way NZ First went, it was bound to disappoint a significant percentage of its support base. This helps to explain why NZ First lost support after the 2017 election.

New Zealand in 2017 didn't experience the right-wing populist surge seen in other western representative political systems (Vowles \& Curtin, 2020). Moreover, it hasn't seen the party 
fragmentation and the decline, if not destruction, of traditional centre-left and centre-right parties, as have other western democracies, notably Italy and France. The National and Labour parties still ruled the roost, receiving $81.3 \%$ of the party vote between them both.

\section{The 2020 election}

Ardern's Labour-led coalition government did last the full three-year term, despite public scepticism about the durability of its tripartite composition. NZ First presented itself as the 'handbrake' on a government that was supposedly in danger of going too far to the left. For example, NZ First used its position to block a proposal for an extended capital gains tax. The Ardern government had faced a series of extraordinary challenges, notably the terrorist attack on mosques in Christchurch in March 2019, the eruption of Whakaari/White Island, and the Covid-19 pandemic. The 2020 election debate was overshadowed especially by the pandemic and six weeks under one of the strictest lockdowns seen in the world (Duncan, 2020a). Concerns about public safety and the ability of parties to campaign freely led to a delay in the polling day by four weeks from 19 September to 17 October. The 2020 Stuff/Massey surveys occurred amid these events and aimed to learn about shifts in public opinion. The subsequent election gave Labour $50 \%$ of the party vote and a majority of seats in the House of Representatives (Table 1). This was the highest vote achieved by any party and the first single-party majority under the MMP electoral system since it began 1996 . The election saw a humiliating defeat for National (down from 44.4\% in 2017 to $25.6 \%$ in 2020), the rise of the ACT party (up from $0.5 \%$ to $7.6 \%$ ) and the demise of NZ First which won no seats at all (down from 7.2\% to 2.6\%). Having won the Waiariki electorate, the Māori Party was returned to parliament with two seats. The Green Party was returned with 10 seats, including the electorate of Auckland Central. The Labour Party formed a post-electoral support agreement with them, giving two leading Green MPs ministerial portfolios outside cabinet, even though this was constitutionally unnecessary for the formation of the government. The surveys reported below, however, were conducted before the election.

\section{Survey method}

The Stuff.co.nz/Massey University Election Survey was an online readership-engagement survey designed to test the mood of the country ahead of the 2017 and 2020 general elections, to provide insights into the issues of importance to New Zealanders, and to uncover underlying concerns around leadership, trust and the political system. The two rounds in late May and early August 2017 attracted unexpectedly high levels of participation $(\mathrm{N}=39,644$ and 49,480 respectively). As they had reached huge audiences and made a positive contribution to public debate around elections, two more were conducted in 2020 .

The readership-driven model applied here is not the traditional one of data collection, then peer-reviewed publication followed by 'knowledge transfer' to an 'end-user'. Instead, there is a more direct and timely feedback-loop between researchers, media and voters. 
Table 1

\begin{tabular}{|l|l|l|l|l|l|}
\hline Election results 2020 & & & & & \\
\hline & $\mathbf{N}$ & $\begin{array}{l}\text { Party } \\
\text { vote } \%\end{array}$ & $\begin{array}{l}\text { Electorate } \\
\text { Seats }\end{array}$ & List Seats & $\begin{array}{l}\text { Total } \\
\text { seats }\end{array}$ \\
\hline Labour Party & $1,443,545$ & 50 & 46 & 19 & 65 \\
\hline National Party & 738,275 & 25.6 & 23 & 10 & 33 \\
\hline Green Party & 226,757 & 7.9 & 1 & 9 & 10 \\
\hline ACT New Zealand & 219,031 & 7.6 & 1 & 9 & 10 \\
\hline Māori Party & 33,630 & 1.2 & 1 & 1 & 2 \\
\hline New Zealand First Party & 75,020 & 2.6 & 0 & 0 & 0 \\
\hline $\begin{array}{l}\text { The Opportunities Party } \\
\text { (TOP) }\end{array}$ & 43,449 & 1.5 & 0 & 0 & 0 \\
\hline New Conservative & 42,613 & 1.5 & 0 & 0 & 0 \\
\hline Advance NZ & 28,429 & 1 & 0 & 0 & 0 \\
\hline
\end{tabular}


For these surveys, voters are experts, as each vote is of equal value in the election and the voter-participants express their own opinions. The Stuff platform provided a link to the survey instrument, and then ran opinion columns by journalists and academics to summarise results with supporting commentary. The aim was to get readers actively engaged, rather than to treat them as passive subjects from whom opinions are extracted for remote statistical analysis in journals that participants can't access.

The unexpectedly high numbers of participants may partly be attributed to the style of questions. They did not use Likert scales. Items were topical and worded in plain language. They needed to be brief for easy completion on a mobile phone. For simplicity, items were largely kept to three options, either in 'Goldilocks' fashion (two opposing extreme statements and one moderate opinion) or in the form of a provocative statement with options to agree, disagree or neither. As this was a collaboration with a news media organization, items that were currently topical and newsworthy were needed, and there was no time available for pretesting. The project needed to meet media and electionrelated deadlines.

Plans for the Stuff/Massey pre-election 2020 surveys were initially to run three rounds: the first sometime after Easter and before the May Budget, followed by two more approaching the election which, at that stage, was scheduled for 19 September. The disruption of Covid19 and the strict lockdown meant that the pre-Budget round didn't proceed. Two surveys were conducted: the first in the week beginning 12 July $(N=73,647)$ and the second in the week beginning 30 August $(N=10,586)$. In 2017, the second round had seen an increase in participant numbers, and there was no obvious single explanation for the drop in numbers this time. The second round had a stronger demographic bias.

Participants were self-selecting. Readers on the Stuff.co.nz website could enter the survey via a banner link. To proceed with the survey they had to confirm that they would be eligible to vote in the forthcoming New Zealand general election. Second attempts to submit a response were blocked. The project was deemed 'low risk' for research ethics oversight (Massey University Human Ethics Committee notification number: 4000022314).

\section{July 2020 (round 1) sample}

In the first of the two surveys (in July 2020) the age-range of participants was 18 to 91; mean 52.1 . The sample had a strong gender bias: $61.2 \%$ male, $37.9 \%$ female, $0.9 \%$ genderdiverse. Aucklanders (15.9\%) were under-represented, given that the Auckland region includes about one third of the total population. (The second round's sample was smaller and more biased, and is relied on less for present purposes.)

According to the 2018 national census, $70 \%$ of New Zealanders were of European origins, 16.5\% Māori, 15.9\% Asian, 8\% Pasifika, and 2.7\% smaller groups. But "'New Zealander" or "Kiwi" responses were coded [in the census] to "other", whilst "Pākeha" was coded to "New Zealand European" at level two of the classification' (Statistics New Zealand Tatauranga Aotearoa, 2021). Those writing 'New Zealander' in the 'other' box and ticking no officially recognised ethnic identity have in the past confounded statisticians and social scientists, but 
the present survey invited this response in order to learn more about those who prefer it over any particular ethnic self-identification. The Stuff/Massey survey had only one level of coding of ethnicity, but it allowed respondents to tick more than one option. This resulted in about $19 \%$ giving 'hyphenated' or hybrid self-identifications. New Zealander, NZ European and Pākeha were offered as distinct options. (Table 2.)

$24.4 \%$ of respondents identified themselves as 'New Zealanders' only. One needs to take account of a conservative and white bias in the sample as a whole, so this is probably an over-estimate compared with the population. Another $11.9 \%$ chose 'New Zealander' but added a further ethnic category. These included NZ European/New Zealander (2.9\%) and Pākeha/New Zealander (2.3\%) and NZ European/Pākeha/New Zealander (2.6\%). There were also small groups identifying as Maori/New Zealander (0.7\%), Maori/NZ European/New Zealander (2.1\%) and Maori/Pakeha/New Zealander (1.3\%). In the overall sample, 36.9\% self-identified solely as NZ European, $8.9 \%$ as Pākeha, $1.7 \%$ as Māori, $1.8 \%$ as Māori/NZ European, $1 \%$ as Māori/Pākeha, $1.8 \%$ as Asian, and $0.6 \%$ as Pasifika. The sample underrepresented ethnic minority groups, but their numbers were high: for example there were 1276 Asian and 450 Pasifika respondents.

There was a wide range of before-tax household incomes reported by participants, but with $25 \%$ at $\$ 150,000$ per annum or above, there was a bias towards higher-income earners. (Table 3.)

Labour supporters were $43.2 \%$, National $36.8 \%$. During July, however, opinion polls had Labour between 53 and 61\%, and National between 25 and 32\%. So, although Labour had the strongest support in this survey, it was still under-represented, especially in light of Labour's $50 \%$ result in the election itself. National supporters were over-represented. (Table 4.)

Overall, then, the survey sample had a bias towards conservative older white male voters. In items where there was an wide gender difference, the results were weighted $50 / 50$. Crosstabulating results by party preferences revealed distributions of responses across the political spectrum.

\section{Sampling issues}

There was no expectation that the Stuff/Massey samples could be representative, as the surveys were designed for voluntary reader participation, and large sample sizes do not necessarily reduce biases. Nonetheless, obtaining representative samples has become a challenge for marketing firms who do 'scientific' surveys. Before the 17 October election, polls overestimated National and underestimated Labour by margins that were outside the normal margin of error (+/-3\%). Average results over the seven polls taken in the five weeks before the polling day were: National $30.9 \%$, Labour $47.3 \%$. The averages of the three polls taken in the two weeks before polling day, while advance polling booths were open, were: National $31.4 \%$, Labour $46.3 \%$. (Table 5.) 
Table 2

\begin{tabular}{|c|c|c|c|}
\hline \multicolumn{4}{|l|}{ Ethnic self-identification } \\
\hline \multirow[t]{14}{*}{ Single ethnicity identifiers } & & $\mathbf{N}$ & $\begin{array}{l}\text { \% of } \\
\text { Total }\end{array}$ \\
\hline & Maori & 1208 & 1.7 \\
\hline & NZ European & 25953 & 36.9 \\
\hline & Pakeha & 6178 & 8.8 \\
\hline & New Zealander & 17181 & 24.4 \\
\hline & European & 1802 & 2.6 \\
\hline & Pasifika & 450 & 0.6 \\
\hline & Asian & 1276 & 1.8 \\
\hline & Middle Eastern & 68 & 0.1 \\
\hline & Latin American & 86 & 0.1 \\
\hline & North American & 249 & 0.4 \\
\hline & African & 173 & 0.2 \\
\hline & Citizen of the world & 879 & 1.2 \\
\hline & Other & 1476 & 2.1 \\
\hline \multicolumn{4}{|l|}{$\begin{array}{l}\text { Bi- and multi-ethnicity } \\
\text { identifiers }\end{array}$} \\
\hline & Maori-NZer & 515 & 0.7 \\
\hline & Maori-NZ European & 1258 & 1.8 \\
\hline & Maori-Pakeha & 687 & 1 \\
\hline & $\begin{array}{l}\text { Maori-NZ European-New } \\
\text { Zealander }\end{array}$ & 1507 & 2.1 \\
\hline & Maori-Pakeha-New Zealander & 928 & 1.3 \\
\hline & Maori-NZ European-Pakeha & 38 & 0.05 \\
\hline & Maori-NZ European-Pakeha-NZer & 214 & 0.3 \\
\hline & NZ European-Pakeha & 1054 & 1.5 \\
\hline & NZ European-Pakeha-NZer & 1800 & 2.6 \\
\hline & NZ European-NZer & 2043 & 2.9 \\
\hline & Pakeha-NZer & 1605 & 2.3 \\
\hline & Other 'hyphenated' identities & 1734 & 2.5 \\
\hline Total & & 70362 & \\
\hline \multicolumn{2}{|l|}{ Respondents who did not co } & 3285 & \\
\hline
\end{tabular}


Table 3

\begin{tabular}{|l|l|}
\hline Household Income Band & $\%$ \\
\hline Up to $\$ 30000$ & 8.2 \\
\hline$\$ 30000$ to $\$ 50000$ & 11.6 \\
\hline$\$ 50001$ to $\$ 70000$ & 13.7 \\
\hline$\$ 70001$ to $\$ 100000$ & 19.5 \\
\hline$\$ 100001$ to $\$ 150000$ & 22 \\
\hline$\$ 150001$ to $\$ 200000$ & 12.6 \\
\hline$\$ 200001$ or more & 12.4 \\
\hline Total & $\mathbf{6 7 7 6 9}$ \\
\hline
\end{tabular}

Table 4

If the election was tomorrow, which political party would you most probably vote for?

\begin{tabular}{|l|l|}
\hline Party & $\%$ \\
\hline National & 36.8 \\
\hline Labour & 43.2 \\
\hline Green & 6.4 \\
\hline NZ First & 1.6 \\
\hline ACT & 8.1 \\
\hline The Opportunities Party & 1.2 \\
\hline Maori Party & 0.4 \\
\hline New Conservative & 1.2 \\
\hline Other & 1.2 \\
\hline Total & $\mathbf{7 0 7 8 1}$ \\
\hline
\end{tabular}




\begin{tabular}{|c|c|c|c|c|c|c|c|c|c|c|c|c|}
\hline \multicolumn{13}{|c|}{ Table 5: Pre-Election Opinion Polls, Sept/Oct 2020} \\
\hline Dates & Pollster & $N$ & Nat & $L a b$ & $N Z F$ & Green & $A C T$ & TOP & Māori & N Cons & $A d v N Z$ & Lab lead \\
\hline 8-15 Oct & $\frac{\text { Newshub-Reid }}{\text { Research }}$ & 1000 & 31.1 & 45.8 & 3.5 & 6.3 & 7.4 & 1.3 & 0.6 & 1.7 & 0.3 & 14.7 \\
\hline 10-14 Oct & $\begin{array}{l}1 \text { News-Colmar } \\
\text { Brunton }\end{array}$ & 1005 & 31 & 46 & 2.6 & 8 & 8 & 1.1 & 0.6 & 1.5 & 0.9 & 15 \\
\hline 3-7 Oct & $\begin{array}{l}\text { 1 News-Colmar } \\
\text { Brunton }\end{array}$ & 1007 & 32 & 47 & 2.4 & 6 & 8 & 1.8 & 0.2 & 1.3 & 0.9 & 15 \\
\hline Sep-20 & $\begin{array}{l}\text { Roy Morgan } \\
\text { Research }\end{array}$ & 911 & 28.5 & 47.5 & 2.5 & 9.5 & 7 & 1.5 & 0.5 & - & - & 19 \\
\hline 23-27 Sep & $\begin{array}{l}1 \text { News-Colmar } \\
\text { Brunton }\end{array}$ & 1005 & 33 & 47 & 1.4 & 7 & 8 & 1 & 0.8 & 1.4 & 0.6 & 14 \\
\hline 16-23 Sep & $\begin{array}{l}\text { Newshub-Reid } \\
\text { Research }\end{array}$ & 1000 & 29.6 & 50.1 & 1.9 & 6.5 & 6.3 & 0.9 & 1.5 & 2.1 & - & 20.5 \\
\hline 17-21 Sep & $\begin{array}{l}1 \text { News-Colmar } \\
\text { Brunton }\end{array}$ & 1008 & 31 & 48 & 2.4 & 6 & 7 & 1.1 & 0.9 & 1.6 & 0.8 & 17 \\
\hline \multicolumn{2}{|c|}{ Mean in advance polling period } & & 31.4 & 46.3 & 2.8 & 6.8 & 7.8 & 1.4 & 0.5 & 1.5 & 0.7 & 14.9 \\
\hline \multicolumn{2}{|c|}{ Mean from mid-September } & & 30.9 & 47.3 & 2.4 & 7.0 & 7.4 & 1.2 & 0.7 & 1.6 & 0.7 & 16.5 \\
\hline \multicolumn{2}{|c|}{ Election: party votes \% } & & 25.6 & 50 & 2.6 & 7.9 & 7.6 & 1.5 & 1.2 & 1.5 & 1 & 24.4 \\
\hline \multicolumn{3}{|c|}{$\begin{array}{l}\text { Means in advance polling period minus } \\
\text { election result }\end{array}$} & 5.8 & -3.7 & 0.2 & -1.1 & 0.2 & -0.1 & -0.7 & 0.0 & -0.3 & -9.5 \\
\hline \multicolumn{3}{|c|}{$\begin{array}{l}\text { Means from mid-September minus election } \\
\text { result }\end{array}$} & 5.3 & -2.7 & -0.2 & -0.9 & -0.2 & -0.3 & -0.5 & 0.1 & -0.3 & -7.9 \\
\hline
\end{tabular}


It looked like the gap between Labour and National was closing, continuing a trend since mid-year when Labour was polling well over $50 \%$. Given those trends, it seemed reasonable to predict that Labour could get 45 to $46 \%$ and National $31 \%$ of the party vote. As it turned out, predictions based on the opinion polls were significantly inaccurate. Labour's election result was $50 \%$, National's only $25.6 \%$. The polls in the preceding fortnight were overestimating National by an average of 5.8 percentage points; they were under-estimating Labour by 3.7 points. The Green and Māori parties were also under-estimated ( 1.1 and 0.7 points respectively). The Māori Party was unexpectedly returned to parliament (after winning no seats in 2017) with one electorate and one list seat. The worst of polling-based predictions, however, was in the hotly-contested seat of Auckland Central. Two polls showed the Green candidate Chloë Swarbrick running third; at the election, she won with a margin of 1,068 votes.

It's in the interests of the polling companies to obtain representative samples and to get honest answers from respondents. The inaccuracy of political polls is a problem that is not unique to New Zealand, however. Experts in the US and Australia have been pondering this since polls in both countries embarrassingly under-estimated election results for right-wing parties (Barnett \& Sisson, 2019; Druke \& Silver, 2020). In New Zealand, by contrast, it's leftwingers who are reluctant to respond to polls, but so far there is no obvious reason why New Zealand should be different in this respect. The Stuff/Massey samples underrepresented Labour supporters, as did the 'scientific' surveys. The problem for New Zealand pollsters is not the hypothetical 'shy Tory'. The jury is still out, however, on the reasons for inaccurate polling in general (although the reduction of landline use is one factor). For the time being, opinion polls should be treated with scepticism (especially if referenced against approaching elections), even though they do seem to indicate general longer-term trends fairly well. The polls did register a strong surge for Labour during the pandemic lockdown, and this was roughly consistent with the election result.

\section{Results}

Some items used in 2017 were repeated in the 2020 Stuff/Massey survey for comparison. Neither sample was representative, and comparisons between the two must be treated with caution, even though they were derived from the same online platform and appeared to have similar levels of conservative or privileged demographic bias. With this reservation in mind, in July 2017 43.6\% rated the mood of the country as 'discontented', while in 2020 only $28.4 \%$ chose that option. On both occasions, the respondents' estimates of 'mood of the nation' were polarized along party lines. Respondents were more likely to rate the country as 'discontented' if the party they supported was on the opposition benches. In 2020 , only $7.7 \%$ of Labour supporters ticked 'discontented', compared with $48.9 \%$ of National supporters. In 2017, supporters of the parties then in opposition (Labour, Green and NZ First) were the most likely to say 'discontented'. In spite of the mid-2020 lockdown, however, respondents as a whole were more likely to rate the mood of the nation as neutral $(46.5 \%)$ than as discontented (28.4\%).

The survey asked which party leader participants felt personally closest to, and whether they agreed or disagreed (or neither) with these statements: "New Zealand's political 
leaders are out of touch with the people", and, "Our political leaders care about the things that people like me really value".

Of those who felt closest to Jacinda Ardern, 51.4\% agreed that political leaders care, and $8.8 \%$ disagreed. Of all those who ticked any other party leader, it was the reverse: $11 \%$ agreed and $52 \%$ disagreed. Of those who felt closest to Ardern, $8.8 \%$ agreed with the statement that political leaders are out of touch with us, while $60.8 \%$ disagreed. Of all the rest, in contrast, $53.1 \%$ agreed that politicians are out of touch, and $15.1 \%$ disagreed. So, although those two questions were asking only about political leaders in general, the results were strongly divided according to whether or not Jacinda was the political leader to whom the respondent felt closest. The survey revealed a degree of 'personalization' in political perceptions (Hakim \& Choi, 2020).

Between the 2017 and 2020 surveys, the percentage of respondents (as a whole) agreeing that political leaders are 'out of touch' dropped from 50 to $32 \%$. And the percentage who say our political leaders don't really care about the things we value dropped from 45 to $31 \%$. Allowing for the limitations of both survey samples and the polarization effect, New Zealanders appeared to have become, on average, less discontented and less distrusting of politicians than before the last election. This may be partly attributed to the influence of Jacinda Ardern, who is the most popular and world-famous New Zealand politician in generations, and who cultivates a media-friendly personality (Hakim \& Choi, 2020; Hakim \& Liu, in press).

We should only read those figures as indicative. To corroborate the general trend, however, during and after New Zealand's strict lockdown in mid-2020 other surveys revealed very high levels of trust and confidence in the government (Colmar Brunton, 2020; Te Kawa Mataaho Public Service Commission, 2021).

While general discontent was apparently not high in mid-2020, there was still some scepticism, especially among supporters of opposition parties, about the Labour-led government's approach to economic recovery. $68.2 \%$ of all respondents rated the government's overall response to Covid-19 as 'successful', and $10 \%$ rated it 'unsuccessful'. But only $39.6 \%$ of National supporters rated it 'successful'. $51 \%$ of all respondents agreed that the government was taking the right approach to dealing with the economic impact, while $32.7 \%$ disagreed. But $65.8 \%$ of National supporters disagreed (Duncan, 2020b).

On the question of rebuilding the economy following the Covid-19 pandemic, $61.8 \%$ opted for 'let's reform the economic system' over 'get back to business as usual' (30.9\%). The reform option was much more strongly favoured by left-wing voters: Greens $92.9 \%$ and Labour $77.9 \%$. In round 2 of the survey, therefore, we gauged public reactions to particular policies that could come up in pre-election debate about the kind of economy that should emerge from the crisis.

$51.4 \%$ of respondents (including $88.7 \%$ of Labour supporters) felt there would be more damage to the economy in the long run if we had not had a strict lockdown; while $36.2 \%$ (including $64.8 \%$ of National and $69 \%$ of ACT supporters) felt the costs of lockdown had been too high and that they outweighed the public health benefits. As for the long-term 
economic recovery, $87.8 \%$ agreed that we need to use this opportunity to support innovations in all aspects of how we do business. Other statements on which the round-two survey found majority across-the-political-spectrum support were: We need to use this opportunity to recognise the economic value of voluntary caring and community work; and, to invest more in scientific research and teaching for the benefit of the nation. There was consistent majority disagreement across the spectrum with a proposal to make it easier for foreign investors to buy land in New Zealand.

Even though the sample had a conservative bias, most respondents across the spectrum approved of the living wage. Making the living wage the legal minimum wage gained roughly $80 \%$ support from Labour and Greens supporters. And only small minorities thought the living wage is 'not a good idea at all': $13 \%$ overall and only $21 \%$ of National supporters. However, $57 \%$ of National supporters agreed that the living wage is a good idea if it's voluntary for employers. (The living wage rate for 2020 was set at $\$ 22.10$ per hour; the legal adult minimum wage was $\$ 18.90$.)

\section{Right-wing opinion}

The samples' conservative biases invited a closer look at right-wing political opinion in New Zealand. $8.1 \%$ of respondents in round 1 said that they would vote for the ACT Party. ACT was rising in the polls up to $6.5 \%$ in July; it won $7.6 \%$ of the party vote in the election. Compared with the other parties in parliament, ACT supporters were the most likely to rate the New Zealand government's overall response to Covid-19 as 'unsuccessful': $29.5 \%$ compared with $9.9 \%$ for the whole sample. They were the most strongly in favour of abolishing the Māori electoral roll: $68.2 \%$ compared with $36.6 \%$ overall. They were more likely to prefer that the government take a 'cautious and sceptical' approach to climate change: $72.5 \%$ compared with $36.4 \%$ overall. And they were more in favour of the country getting back to 'business as usual' (rather than reforming the economic system itself) during the post-pandemic rebuild: $75 \%$ compared with $31 \%$ overall. Sizeable minorities of them agreed with conspiracy theories about Covid-19 (25\%) and hoped that Donald Trump would be re-elected (32\%) - more than among the National supporters who stood at about $20 \%$ on both points (Duncan, 2020c).

Roughly one in ten New Zealanders supported Donald Trump as President of the United States (Duncan, 2020d). After weighting for gender (as men were more likely than women to support Trump, and the sample had a male bias) $11 \%$ of the Stuff/Massey respondents said they hoped Trump would win America's November 2020 election. This support was evenly spread across age-groups, but slightly higher (15.4\%) in the 18-24 range. It was distributed evenly across lower and middle income brackets, and declined only slightly in the upper income brackets. But $15.6 \%$ of Pasifika respondents and $20 \%$ of those who ticked the 'gender-diverse' box hoped Trump would win - above the overall $11 \%$ result. $92 \%$ of the Trump supporters said we should leave statues of figures from our colonial past where they are, compared to the $49.8 \%$ of those who hoped Trump would lose.

Only $4.9 \%$ of the Trump supporters chose the populist Winston Peters as the party leader they felt closest to, perhaps because of his coalition with Labour after the 2017 election. 
They were more attached to National's Judith Collins (46.6\%) and ACT Party leader David Seymour (30.2\%). Only $20 \%$ of National supporters overall said they hoped Trump would win. But this sub-group of National supporters made up $56 \%$ of the entire cohort of the survey's Trump supporters. A further $23 \%$ of them supported ACT. The far-right New Conservative Party's supporters were $1.2 \%$ of the Stuff/Massey sample; that party won only $1.5 \%$ of the vote at the October election. But $69 \%$ of them supported Trump.

46.5\% of the Trump supporters endorsed conspiracy theories about the Covid-19 virus: that it was either 'an invention of shadowy forces that want to control us' $(11 \%)$ or 'a biological weapon created by one of the world's super-powers' (35.5\%). Only 7.7\% of Trump opponents ticked one of those two statements. $85.8 \%$ of the total sample agreed that the virus came from a natural source; in the round 2 survey, $87.2 \%$ agreed that we should all keep up to date with vaccinations. In general, the further to the right on the political spectrum, the more likely it was that respondents were sceptical about vaccines or about the origin of Covid-19. Only $11.7 \%$ of Trump supporters agreed the New Zealand government was taking the right approach to dealing with the economic impact of Covid-19, while $62 \%$ of Trump opponents agreed. And $84 \%$ of respondents who hoped Trump would win preferred that the New Zealand government take a 'cautious and sceptical' approach to climate change, compared with $23.8 \%$ of Trump opponents. So Trumpism is a global phenomenon, and this includes a minority in New Zealand (Wodak \& Krzyżanowski, 2017)

\section{Ethnicity and political opinion}

Self-identified 'New Zealanders' who chose not to qualify their nationality with ethnicity are demographically diverse, but slightly older, more often male, more often from the South Island, and less affluent than the overall sample. On survey items ranging from the mood of the nation, to rating the government's response to Covid-19, they were more critical of the government compared to Pākeha, while NZ Europeans were somewhere in between. They were more likely to be National Party supporters (47.9\%), who advocated taking a cautious and sceptical stance towards climate change, while Pākeha were more likely to be Labour supporters (56.3\%) in favour of taking urgent action in response to climate change. NZ Europeans were in between, with 39\% for National and $43 \%$ for Labour, and they were slightly more in favour of urgent action on climate change (39\%) compared to being cautious and sceptical (36\%).

Those who self-identified as 'New Zealanders' were the only group with a majority in favour of abolishing the Māori seats in Parliament (50.9\%), whereas $70.3 \%$ of Pākeha and $70.5 \%$ of Māori were in favour of keeping them. Pasifika were mostly in favour of keeping the Māori seats (60\%) compared with NZ Europeans (33.7\%) and Asians (33\%).

Furthermore, while no group had a majority in favour of taking down statues commemorating New Zealand's colonial past, self-identified New Zealanders (74.9\%) were most in favour of leaving them in place but only $27.5 \%$ of Pākeha and $40.7 \%$ of Māori agreed with that. NZ Europeans were largely in favour of leaving the statues in place (63.4\%), compared with $54.4 \%$ of Asians and $46 \%$ of Pasifika. Only 33.5\% of Māori respondents chose the option 'Take them down, they offend the victims of colonization', on other hand. 
Self-identified New Zealanders were the most conservative ethno-national group. Their claim to being ethnicity-free is correlated with differences between themselves and other New Zealanders in terms of political attitudes and party affiliations. Furthermore, many New Zealanders do not think of their group identities in singular terms, but as hybrid. 19\% of the total sample represented themselves as 'hyphenated'.

Pākeha as either a stand-alone category or hyphenated with NZ European or New Zealander included people who were happier with the incumbent government, politically liberal and supportive of Māori seats. Those who called themselves Pākeha were closer to majority Māori and more liberal opinions. The hyphenated category Māori-Pākeha was similar: this group was more approving of the government, more liberal and valued biculturalism and keeping the Māori seats in Parliament even more than those who identified solely as Māori.

In contrast, those who identified as hybrid Māori-NZ Europeans were less likely to value New Zealand as a bicultural nation, less likely to support keeping the Māori seats and more in favour of leaving colonial era statues in place than Māori-only self-identifiers. Overall, Māori in the sample were three times more likely to hyphenate their identities than to choose Māori as a stand-alone identity. Those Māori who hyphenated their ethnicity felt better off (and were economically better off) than those who identified solely as Māori. They were more likely to rate the country as contented, police as able to protect our communities and the government's response to Covid-19 as successful.

At the other end of the spectrum, NZ European-New Zealanders were about as conservative and unhappy with the government as those identifying solely as New Zealanders. Furthermore, $2.6 \%$ of the sample were double-hyphenated Pākeha-NZ European-New Zealanders. This group had liberal attitudes like Pākeha sometimes, but on most issues their liberal-leaning views were moderated by other, more conservative aspects of their hyphenated identity. Asians and NZ Europeans were more likely to present solo identities, whereas Māori, Pasifika and Pākeha were more likely to self-identify as hyphenated rather than choose a single ethnic label (Liu \& Choi, 2020).

Despite these differences, there were also important points of similarity that united New Zealanders of all ethnic identifications. All groups, whether single-identified or hyphenated, most frequently thought the best thing about New Zealanders was that 'they believe that people in genuine need should be given a helping hand' (overall, $51.7 \%$ ). $20.4 \%$ of respondents on this item favoured the more social-democratic view that 'they want all Kiwis to get a fair share of the society's wealth', while $27.9 \%$ opted for the individualist principle that 'people reap the rewards they've worked for'.

On the character of the nation itself, respondents were asked, 'Which of the following do you value the most? New Zealand is a bicultural nation, a multicultural nation, or a free democratic nation'. Overall $60.5 \%$ opted for 'free democratic nation'. Among those identifying solely as Māori, $48.7 \%$ preferred 'free democratic nation', $34.3 \%$ chose 'multicultural nation' and only $17 \%$ chose 'bicultural nation'. This Māori response came as a surprise. One may ask if the sub-sample of Māori respondents was biased just as the overall 
sample was. On the other hand, it was no surprise that $60.4 \%$ of Asian and $60.9 \%$ of Pasifika respondents preferred 'multicultural nation'.

Overall, the Pasifika opinion profile resembled Pākeha, Māori opinion was distributed like Pākeha or NZ Europeans, while Asians were similar to NZ Europeans or New Zealanders, depending on the issue. There may be just as much, if not more, diversity in the political opinions of different groups of white New Zealanders compared with the differences between ethnic groups. Standardised statistical representation of the New Zealand population by ethnic group (NZ European, Māori, Pasifika, Asian) may be masking important differences between sub-cultures.

\section{Discussion}

The Stuff/Massey survey was not representative of the New Zealand population eligible to vote in the general election. The samples consistently under-represented Labour supporters in particular, and they could not have been used for reliably anticipating, let alone predicting, any electoral outcomes. Nevertheless, especially when the results were crosstabulated with political party support, they produced useful and meaningful profiles of distributions of political opinions. Its short punchy questions produced results that had strong prima facie validity, with strong left to right polarization on controversial items such as climate change responses. It was 'quick and dirty' in execution but made a contribution to the pre-election national conversation; it took public opinion seriously, without judgement, across the political spectrum. And it fed its results directly back to the participants and others for their information and to deepen our understanding of our political community as a whole, rather than locking them up behind pay-walls. We maintain that it helped to get people out of echo-chambers and hence to reduce polarization.

From a scientific standpoint, however, these online polls are problematic: participation is initiated by the readers of one particular news-site, and the samples have a conservative older male bias. More work can be done to 'rake' samples that more closely resemble population demographics. The results reported here have not had that fine-grained analysis. But polling agencies around the world and in New Zealand are finding it increasingly difficult to obtain representative samples. Political polls are often unreliable guides to forthcoming electoral outcomes. In New Zealand, younger left-leaning voters are harder to reach and/or more reluctant to respond to calls from polling companies. All four of the Stuff/Massey surveys under-represented Labour support. They had to meet news-media as well as academic interests, and there were tighter timeframes than social scientists would normally prefer. Results should not be taken as 'accurate' in terms of the New Zealand population, but they do reveal trends and patterns that are corroborated roughly by other surveys.

In her election night speech, Ms Ardern said we need to avoid political polarization, without having time to elaborate on what she meant by that. Polarization becomes dangerous when it goes beyond lively or passionate disagreement about policies and values - when opposing camps desire the defeat of their opponents above collective action or social wellbeing. When large-enough sections of the principal opposing political camps hate each other enough to deny one another legitimacy simply as participants in the political arena- 
typifying one another as evil, insane, seditious or foreign-influenced - then a political community has reached a stage of polarization at which collaboration, reform and progress become almost impossible. The opposition is ruled out as if having no valid place in the community. One's allies ban one from collaborating with opponents, open dialogue is shut down, the nation sorts itself into factions along ideological, ethnic or religious lines, and civil disorder, if not civil war, may tragically be the next stage. This trend is starkly visible in the United States (Hetherington \& Rudolph, 2015; Mason, 2018).

In general, shutting down voices or banning opinions that we do not want to hear is a symptom of political polarization, not a solution. Censorship is warranted only for demonstrably harmful and objectionable ideas such as the manifesto of the terrorist who attacked mosques in Christchurch. Once we lose the courage to talk openly with one another about our passionately held but widely differing views on critical issues, then opponents lack opportunities to understand one another and make compromises, and we embark on a downward journey of radicalization and polarization. With the affordances of digital media, furthermore, disinformation campaigns can accelerate this process (Vosoughi, Roy, \& Aral, 2018).

The aims therefore of the Stuff/Massey survey were to elicit the spectrum of opinions in New Zealand, reflect this political diversity back to the public, and stimulate an open and mature election debate. In the process, we found some predictable distributions of opinions. We also uncovered some nuances as some opinions did not fall predictably into ethnic-group categories. For example, more research is called for on the surprising result that only a minority of Māori respondents regarded biculturalism as a most highly valued characteristic of New Zealand, while they showed a greater preference for the values of 'free and democratic'. It may be of interest to investigate whether the slightly higher rate of support for Trump among Pasifika in this survey is replicated in others, and hence ask why this is the case. Furthermore, 'mainstream' white New Zealanders are highly diverse in their political opinions and values, as are the members of minority ethnic groups. The four surveys in 2017 and 2020 revealed a strong current of right-wing populist 'Trumpist' opinion that, to a large extent, had been represented (and domesticated) by the centrist NZ First party. Now that NZ First has been eliminated from parliament, possibly for good, one asks what kinds of political leadership will come forward to fill that gap. New Zealand may follow overseas trends (Wodak \& Krzyżanowski, 2017), as its underlying economic and monetary policies are similar to other countries in the western world (Blyth, 2016).

Covid-19 occasioned emergency powers and the suspension of civil and economic liberties. New Zealanders mostly complied with the government's orders and the public-health outcomes have been relatively good with low infection and mortality rates. The Stuff/Massey survey corroborated others that showed that New Zealanders largely trusted the government's lead, and the Labour Party's strong election result reflected this with a surge from $36.9 \%$ in 2017 to $50 \%$ in 2020 . The adverse consequences of effective pandemic management (and occasional mismanagement) can lead to blame and division, however, as people fear further lockdowns and businesses are affected. While the Labour government's disease-control measures have been basically successful and have called for social responsibility and sacrifices from communities, it's difficult for a centre-right opposition that largely favours the business community and values individual responsibility to find 
opportunities for critical messaging. Should a pro-business opposition call for a return to 'normal' economic activity, and hence risk increased disease transmission, or call for even tighter lockdown and border-control regimes? Former prime minister John Key suggested the economic crisis was more important than the public health risk, but the current National Party leader Judith Collins argued that a government led by her would have been stricter in controlling movements across the border. The Stuff/Massey survey suggested that roughly one in every eight New Zealanders is prone to Covid-related or anti-vaccination scepticism. And among supporters of the National and ACT parties the opinion that the economic costs of lockdown outweighed the public health benefits was upheld by about two thirds. No progress can be made by outright dismissal of such minority opinions or (worse) by ad hominem attacks on people who express those opinions. Only patient and detailed government, effective pandemic management and economic recovery measures can ensure that such sentiments do not boil over into disruptive political action and opposing reactions.

\section{Conclusion}

Despite the limitations of online surveys, the Stuff/Massey survey has been a useful exercise for social scientists. It asked novel questions in an accessible style that elicited very large samples. While one cannot reach firm conclusions about the findings (other than when corroborated by comparable results) they may stimulate further research. While these surveys revealed attitudes that could be mobilised by disruptive populist leaders, there was an encouraging indication that the mood of the nation and trust in the government had improved, even under emergency conditions, or perhaps because of the emergency.

With the electoral success of a traditionally social-democratic Labour Party, the rising trust in government, and the successful strategy to eliminate the Covid-19 virus, New Zealand was an outlier in the broadly-defined 'western democratic' world in 2020. One way or another, the pandemic creates a transformative moment in world history and in New Zealand society. It has led to a sense of social solidarity in some respects, but it has also exacerbated inequalities and divided opinions. The Stuff/Massey survey has revealed some of these underlying social fissures.

\section{Acknowledgements}

We gratefully acknowledge the team at Stuff who supported this survey (despite difficult times for media) and used its results in their reporting especially Luke Malpass, Tracy Watkins, Kathrin Goldsworthy, Eugene Bingham and Adam Dudding, the editors of The Conversation especially Finlay Macdonald, and the communications team at Massey University especially Jennifer Little and Mike Shaw. Sidah Russell made the surveys happen in 2017 and 2020 and won the project an award from the Public Relations Institute of New Zealand in 2018. 


\section{References}

Abramowitz, M. J. (2018). Democracy in Crisis. In Freedom in the World 2018. Freedom House.

Barnett, A., \& Sisson, S. (2019, May 21). Here's how to make opinion polls more representative and honest. Retrieved February 2021, from The Conversation: https://theconversation.com/heres-how-to-make-opinion-polls-morerepresentative-and-honest-117405

Blyth, M. (2016). Global Trumpism. Foreign Affairs, 15, retrieved March 62021 from https://www.foreignaffairs.com/articles/2016-11-15/global-trumpism

Colmar Brunton. (2020, April 24). COVID Times, Edition 3: Backing New Zealand. Retrieved May 2020, from Colmar Brunton: https://static.colmarbrunton.co.nz/wpcontent/uploads/2019/05/COVID-Times-24-April-2020.pdf

Cuperus, R. (2018). Social Democracy and the Populist Challenge. In R. Manwaring, \& P. Kennedy, Why the Left Loses: The Decline of the Centre-Left in Comparative Perspective (pp. 185-202). Bristol: Policy Press.

Druke, G., \& Silver, N. (2020, November 12). Politics Podcast: Why Polls Were Off in 2020, and Why They Weren't That Bad. Retrieved February 2021, from FiveThirtyEight: https://fivethirtyeight.com/features/politics-podcast-why-polls-were-off-in-2020and-why-they-werent-that-bad/

Duncan, G. (2018a). The 'soft target' of Labour in New Zealand. In R. Manwaring, \& P. Kennedy, Why the left loses: The decline of the centre-left in comparative perspective (pp. 53-67). Bristol: Policy Press.

Duncan, G. (2018b). Trust, distrust, and the end of politics-as-we-knew-it: the mood of the nation prior to election 2017. Kōtuitui: New Zealand Journal of Social Sciences Online, 13(2), 114-131.

Duncan, G. (2020a). The Covid-19 pandemic. Policy Quarterly, 16(3), 3-6.

Duncan, G. (2020b, July 26). Are we less grumpy after Covid? Retrieved March 2021, from Stuff: https://www.stuff.co.nz/national/politics/opinion/300065705/are-we-lessgrumpy-after-covid

Duncan, G. (2020c, October 7). The rise of ACT in 2020 highlights tensions between the party's libertarian and populist traditions. Retrieved March 2021, from The Conversation: https://theconversation.com/the-rise-of-act-in-2020-highlightstensions-between-the-partys-libertarian-and-populist-traditions-147170

Duncan, G. (2020d, November 6). Who are Donald Trump's supporters in New Zealand and what do we know about them? Retrieved March 2021, from The Conversation: https://theconversation.com/who-are-donald-trumps-supporters-in-new-zealandand-what-do-we-know-about-them-149424

Foa, R. S., \& Mounk, Y. (2017). The Signs of Deconsolidation. Journal of Democracy, 28(1), 515.

Foa, R., Klassen, A., Slade, M., Rand, A., \& Williams, R. (2020). The Global Satisfaction with Democracy Report 2020. Cambridge UK: Centre for the Future of Democracy.

Friedman, U. (2016, July 1). Trust in Government Is Collapsing Around the World. Retrieved November 10, 2016, from The Atlantic: http://www.theatlantic.com/international/archive/2016/07/trust-institutionstrump-brexit/489554/ 
Grzymala-Busse, A. (2019). The Failure of Europe's Mainstream Parties. Journal of Democracy, 30(4), 35-47.

Hakim, M. A., \& Choi, S. (2020, August 16). Jacinda Ardern's star power comes with risks. Retrieved March 2021, from Stuff: https://www.stuff.co.nz/national/politics/opinion/300083151/jacinda-arderns-starpower-comes-with-risks

Hakim, M., \& Liu, J.H. (in press). Development, construct validity, and measurement invariance of the parasocial relationship with political figures (PSR-P) scale. International Perspectives in Psychology: Research, Practice, Consultation.

Hetherington, M., \& Rudolph, T. J. (2015). Why Washington Won't Work: Polarization, Political Trust, and the Governing Crisis. Chicago: University of Chicago Press.

Lees-Marshment, J., Dufresne, Y., Eady, G., Osborne, D., van der Linden, C., \& Vowles, J. (2015). Vote Compass in the 2014 New Zealand election. Political Science, 67(2), 94124, DOI: $10.1177 / 0032318715609076$

Levitsky, S., \& Ziblatt, D. (2018). How Democracies Die. New York: Crown.

Liu, J. H., \& Choi, S. Y. (2020, August 9). Identity Politics and Hyphenated Identities: What do New Zealanders really want for our political future? Retrieved March 2021, from Stuff: https://www.stuff.co.nz/national/politics/300077289/identity-politics-andhyphenated-identities-what-do-new-zealanders-really-want-for-our-political-future

Mason, L. (2018). Uncivil Agreement: How Politics Became Our Identity. Chicago: University of Chicago Press.

Mounk, Y. (2018). The People vs. Democracy: Why Our Freedom Is in Danger and How to Save It. Cambridge MA: Yale University Press.

Mudde, C. (2019). The 2019 EU Elections: Moving the Center. Journal of Democracy, 30(4), 20-34.

Pew Research Center. (2015). Beyond Distrust: How Americans View Their Government. www.pewresearch.org.

Ries, T. (2017, January 15). The Fall of Trust, the Rise of Populist Action. Retrieved January 17, 2017, from Edelman: http://www.edelman.com/post/fall-of-trust-rise-ofpopulist-action/

Runciman, D. (2017, December 28). Nobody Knows Anything. Retrieved January 11, 2018, from Talking Politics: https://www.acast.com/talkingpolitics/nobodyknowsanything

Runciman, D. (2018). How Democracy Ends. Chicago: Basic Books.

Solijonov, A. (2016). Voter Turnout Trends around the World. Stockholm: International Institute for Democracy and Electoral Assistance.

Statistics New Zealand Tatauranga Aotearoa. (2021). Ethnicity (information about this variable and its quality). Retrieved March 2021, from StatsNZ: http://datainfoplus.stats.govt.nz/Item/nz.govt.stats/7079024d-6231-4fc4-824fdd8515d33141

Te Kawa Mataaho Public Service Commission. (2021, February 22). Trust and confidence in the Public Service. Retrieved March 2021, from Our Work: https://www.publicservice.govt.nz/our-work/trust-and-confidence-in-the-publicservice

Twenge, J. M., Campbell, W. K., \& Carter, N. T. (2014). Declines in Trust in Others and Confidence in Institutions Among American Adults and Late Adolescents, 19722012. Psychological Science, 25(10), 1914-1923. 
van der Meer, T., \& Zmerli, S. (2017). The Deeply Rooted Concern with Political Trust. In S. Zmerli, \& T. van der Meer, Handbook on Political Trust (pp. 1-15). Cheltenham: Edward Elgar.

Vosoughi, S., Roy, D., \& Aral, S. (2018). The Spread of True and False News Online. Science, 359(6380), 1146-1151.

Vowles, J., \& Curtin, J. (2020). A Populist Exception? The 2017 New Zealand General Election (http://doi.org/10.22459/PE.2020). Canberra: ANU Press.

Wedel, J. R. (2016, November 7). Donald Trump and a World of Distrust. Retrieved November 10, 2016, from Project Syndicate: https://www.projectsyndicate.org/commentary/public-trust-deficit-trump-by-janine-r--wedel-2016-11

Wodak, R., \& Krzyżanowski, M. (2017). Right-wing populism in Europe \& USA: Contesting politics \& discourse beyond 'Orbanism'and 'Trumpism'. Journal of Language and Politics, 16(4), 471-484. 